UDC: $342.5(477): 530.1 " 15 "$

\author{
Dmytro Vashchuk, \\ Candidate of Historical Sciences (Ph.D. in History), \\ Senior Research Fellow, Institute of History of Ukraine \\ National Academy of Sciences of Ukraine (Ukraine, Kyiv), \\ dmvashchuk@gmail.com, \\ orcid.org/0000-0003-0377-1233
}

\title{
THE STATE STRUCTURE OF THE GRAND DUCHY OF LITHUANIA IN LIGHT OF HISTORIOGRAPHICAL CONCEPTS
}

The second half of the $14^{\text {th }}$ century became a landmark for Central and Eastern Europe. The vast majority of the former Rus-Ukraine land became part of Grand Duchy of Lithuania (GDL) when the Gediminids dynasty gained a foothold. The process of the state structure developing for GDL began taking into account the annexed territories. The relevant subject of research is the state formation that determines its territorial and national-territorial organization. The stated problem is extremely complex. Therefore we took into account the important facts of the historiographical works in which the researchers studied GDL state structure.

Despite the curiosity of this problem, the topic is not popular in modern historiography. The vast majority of researchers (except some scientists) do not dive into the essence of the problem but adhere to the views of the classics in the Lithuanistics of the late 19th - the first third of the 20th century. Unfortunately the source base is rather limited (especially related to the second half of the $14^{\text {th }}$ - the first half of the $15^{\text {th }}$ century). And it is not about the absence of chronicles or acts as to some extent they are sufficient. The question is how much they relate directly to the problem we outlined.

The concept of GDL federated system was the most widespread and is up to now to some extent. M. Lyubavsky, M. Dovnar-Zapolsky, M. Hrushevsky, R. Lashchenko and M. Chubaty were its ardent supporters. This concept has been reflected partly for the last several decades in the works of the researchers F. Shabuldo, E. Gudavichius, O.Rusyna. F. Leontovich, to some extent $O$. Yefimenko, N. Molchanovsky and V. Zaikin had been the critics of this theory. A completely different version was proposed by the modern researcher Z. Norcus. In his view GDL was an empire in the form of government. 
Taking into account the fact that the issue of Grand Duchy of Lithuania state structure is not completely studied, we consider it is necessary to prepare an appropriate historical and legal research.

Keywords: Grand Duchy of Lithuania, state structure, federation, unitary state, empire, historiography, historical and legal researches.

\section{Дмитро Ващук, кандидат історичних наук, старший науковий співробітник, Інститут історії України Національної академії наук України \\ (Україна, Київ), dmvashchuk@gmail.com, orcid.org/0000-0003-0377-1233 \\ ДЕРЖАВНИЙ УСТРІЙ \\ ВЕЛИКОГО КНЯЗІВСТВА ЛИТОВСЬКОГО У СВІТЛІ ІСТОРІОГРАФІЧНИХ КОНЦЕПЦІЙ}

Друга половина XIV cm. стала знаковою для Центрально-Східної Європи. Переважна більшість земель колишньої Русі-України увійшли до складу Великого князівства Литовського (далі ВКЛ), у якому утвердилась династія Гедиміновичів. Розпочався процес формування державного устрою ВКЛ з урахуванням приєднаних територій. Відповідно предметом дослідження є вивчення форми держави, котра визначає його територіальну та національно-територіальну організацію. Поставлене проблема є надзвичайно складною. Тому, наразі, об'єктом нашої уваги будуть історіографічні праці, у яких учені досліджували державний устрій ВКЛ.

Незважаючи на цікавість поставленої проблеми, у сучасній історіографії тема не є популярною. Переважна більшість дослідників (за винятком окремих учених) не заглиблюються у суть проблеми, а дотримуються поглядів класиків литуаністики кінця ХІХ-першої третини ХХ ст. Джерельна база, на жаль, досить обмежена (особливо це стосується другої половини XIV - першої половини XV cm.). Причому мова не йде про відсутність літописних чи актових матеріалів, бо певною мірою їх достатньо. Питання в тому, наскільки вони безпосередньо стосуються окресленої нами проблеми.

Найпоширенішою була, і певною мірою є досі, концепція про федеративний устрій ВКЛ. Ї̈̈ завзятими прихильниками були М. Любавський, М. Довнар-Запольський, М. Грушевський, Р. Лащенко, М. Чубатий. Серед дослідників останніх декількох десятиліть ця концепція, чатсково, знайшла відображення у працях Ф. Шабульдо, Е. Гудавичюса, О. Русиної. Критиками вказаної теорії виступили Ф. Леонтович, певною мірою О. Єфименко, Н. Молчановський та В. Заїкин. Цілком іншу версію запропонував сучасний дослідник 3. Норкус. На його думку ВКЛ за формою державного устрою було імперією. 
Враховуючи цілковиту невивченість питання державного устрою ВКЛ, вважаємо за необхідне підготовки відповідного історико-правового дослідження.

Ключові слова: Велике князівство Литовське, державний устрій, федерація, унітарна держава, імперія, історіографія, історико-правові дослідження.

The second half of the $14^{\text {th }}$ century became a landmark for Central and Eastern Europe. Olger Gediminid, Grand Duchy of Lithuania (GDL) Governor, managed to win a number of victories over the Golden Horde troops and to join the vast majority of the former Rus-Ukraine lands to his possessions. This is how the new dynasty, the Gediminids, emerged which for several centuries dominated over the eastern frontiers of European civilization. Undoubtedly the primary task for the new government was the formation of the state authorities, political institutions and border security. That is the process of the state structure formation for GDL had been taking place including the annexed territories. Accordingly the main purpose of the publication is to study the form of the state that determines its territorial and national-territorial organization. The stated problem is extremely complex. Completely resolving it within a single publication is impossible. Therefore, for now, the object of our attention will be the historiographical works in which reserchers studied GDL state structure. In its turn it will facilitate further historical and legal research of this area.

Despite the curiosity of this problem, the topic is not popular in modern historiography. The vast majority of researchers (with the except of some scientists, discussed below) do not dive into the essence of the problem, but adhere to the views of the classics of Lithuanistics at the end of the $19^{\text {th }}$ - first third of the $20^{\text {th }}$ century. Obviously it depends on several problems. In our view the first one is that GDL like any other state had undergone reform processes while its developing. Accordingly there was a change in the state structure at different times, as a result it complicates the formulation of generalized conclusions. The second problem is related to a limited source base. And it is not about the absence of chronicles or acts because to some extent they are sufficient. The question is how much they relate directly to the problem we outlined. The third problem relates to the methodological foundations of historical legal studies, including the narrow-profile studies to which this study belongs.

The vast majority of scholars from different countries and at different times paid attention not so much to the state-legal status of individual lands / principalities within the GDL, but to the whole state structure as it was. The most widespread was, and to some extent is, the concept of a federated GDL system. One of the most influential Lithuanian historians of the second half of the $19^{\text {th }}$ and early $20^{\text {th }}$ centuries M. Lyubavsky noted: "All other lands that had been 
joined the Lithuanian-Rus state took a separate position from Lithuania as independent parts of the state united only by a single power. Their state position in connection with their governmental status wich had the stamp of the ancient identity made them look like members of the political federation" (Liubavskyi, 1892: 26). This feature was preserved later as well, namely during the reign of Casimir, Alexander and Sigismund: "The Lithuanian-Rus state in the defined period had a federal character, without losing it until the very end of its independent existence" (Liubavskyi, 1915: 87-88).

M. Dovnar-Zapolsky also held the same opinion. Pointing to the peculiarities of the annexed territories relationship with the central government, the scientist argued that "the whole state could be recognized as built on a federal basis, albeit a little peculiar. This state organization peculiarity consists in some kind of deviations from pure scheme of the federal system" (Dovnar-Zapolskyi, 1901: 85).

M. Grushevsky also wrote about the federation of the GDL. He believed that "GDL did not turn into the centralized state either while Vytovt reign, or later" (Hrushevskyi, 1998: 10). Though the scientist agreed in general with the conclusions of M. Lubavsky and M. Dovnar-Zapolsky at the same time he expressed some of his reasoning: "It only was a rapprochement with the federal system not a true federation because until the second half of the $16^{\text {th }}$ century neither detailed forms, nor representations of land in the central organs, nor forms of local selfgovernment were produced. And the central government itself did not have the character of an authority elected by members of the federation. Eventualy integrity of lands was broken inside via the chain of the new fenomenons social and political by nature, and they pulled deeper into its system" (Hrushevskyi, 1998: 14).

This concept did not raise any objections among individual historians of law. Let's say it was fully supported by R. Lashchenko. According to him, Kyiv region, Volyn, Podillya and Chernihiv-Sivershchyna "being the part of the Grand Duchy of Lithuanian, these lands, with their entire system of volosts (parishes) in each, retained their independence according to their ancient customs. These principalities dependence from the centre consisted mainly in that they had to pay tribute to the Grand Duchy of Lithuania, the so-called "tribute" and to participate in military campaigns on behalf of the owner. Thus the whole state structure was a federal by nature"(highlighted in ed.) (Lashchenko, 1924: 10-11).

M. Chubaty also considered the state structure of GDL as federation: "The federal character of the whole land is manifested in the federation of lands for small Ukrainian provinces, official princes, commoners, the lords' and landowners' feuds, Church, estates and cities with Magdeburg law" (Chubatyi, 1947: 4).

The authority of the voiced findings by well-known scientists of the second half of the $19^{\text {th }}$ - early $20^{\text {th }}$ centuries was so "infallible" that they are present in modern historiography. In particular, Lithuanian historian E. Gudavichius in support of the well-established opinion about the form of the GDL state system, 
noted: "Within the whole Lithuanian state since the $16^{\text {th }}$ century a federation of lands of a new estates [stanova] structure was formed. The core of which was three Lithuanian provinces [voevodstvo] (Vilenske, Troitske Zhmudske elderships [starostvo] - D.V.) which had a clear political hegemony. The state had not been fully centralized but it was united by a single system of territorial government positions" (Hudavychius, 2005: 406). At the same time the scientist claimed that the Grand Duke of Lithuania Vitovt by his actions in domestic politics "essentially destroyed the system of separate principalities ... However, as a result of the crisis in the thirties of the $15^{\text {th }}$ century in the Rus' lands the appanage possessions of the Gediminids top appeared. They were destroyed by 1470" (Hudavychius, 2005: 393). The Ukrainian historian 0. Rusyna also mentioned the autonomy of principalities on Ukrainian lands as part of the Lithuanian state. In her opinion, the vassal dependence of Volodymyr Olgerdovych, Dmytro-Korybut Olgerdovych, Fedir Lyubartovych and others from the Lithuanian prince Jagiello "found outward expression in "obedience", payment of annual tribute and, if it was necessary, providing military assistance to the "master"; apart from that their possessions remained virtually autonomous parts of the Lithuanian state" (Rusyna, 1998: 69). F. Shabuldo believed the autonomy of the principalities remained even after the abolition of the separate principalities at the end of the 14th century: "And in the status provinces [voevodstvo] former principalities remained separate administrative territorial units which kept significant feudal autonomy though often with outlines of borders which had been changed" (Shabuldo, 1987: 103).

At the same time there are several other concepts for this problem. In the fullness of time, the above conclusions of M. Lyubavsky had been criticized by the famous historian of law F. Leontovych. He believed that "there can hardly be a political federation where the union agreement established today is being broken tomorrow, where the federal part falls away from its whole, quite often by purely accidental circumstances, as it was the usual case in specific Rus ... It is even less appropriate to speak about the "federal" nature of the Lithuanian-Rus state in the $15^{\text {th }}$ and $16^{\text {th }}$ centuries" (Leontovych, 1894: 178-179(2)). F. Leontovich also spoke about the impossibility of using the existing statute certificates of Zemstvo as an argument in the matter of the federal system. According to these documents, the domestic life of the lands was carried out "not by their political separation and identity, not by the right of the territorial self-government (political decentralization), but only by granting, that was very fragile and not a strong argument, which could be deprived of any power and at any moment by the will of the same authority which gave it" (Leontovych, 1894: 178-179).

The well-known researcher 0. Yefymenko expressed an interesting opinion. She believed that the principalities that were part of the GDL possessed some sovereignty from the central government untill the middle of the $15^{\text {th }}$ century. The researcher wrote: "There is no state in the specific period but rather the assembly of the states, since each principality was politically independent. The Lithuanian- 
Russ state is undoubtedly a state, but still very far from its future unification. Kyiv, Volyn and Podillya regions have retained much of their regional identity, which was reflected in particular tribal differences and long-lasting political isolation" (Efymenko, 1906: 105-106).

N. Molchanovsky wrote about the political independence elements of separate principalities, in particular Podillya. In his opinion the rulers of Podillya princes "The Koriatovichis could enter into relations with the Polish and Hungarian kings, could seek their friendship and support, establish trade relations with the institution, etc., but Podillya as it is,which was inhabited mainly by the Rus tribe, had a politically independent position under the Koriatovichis" (Molchanovskyi, 1885: 226-227). N. Molchanovsky's findings were substantially reinforced in one of our previous publications. Having analyzed a considerable mass of various written and archeological sources, we came to the conclusion the Koryatovichis princes while ruling by Podil land managed to achieve sovereignty from the central power of the GDL. It was reflected in their legal, political, military, economic and cultural activities (Vashchuk, 2018: 4-19).

Another researcher V.Zaikin identified several periods in the process of development for the form of the GDL state system. The first period refers to the times of Vitovt, who "tried to create a unitary (monolithic) state out of all the lands which were subordinated to him, but having met resistance from some (especially Ukrainian) lands, he had to leave them limited statehood". In the second stage which came after Vitovt's death, "the lands united by him formed a federal Lithuanian-Ukrainian-Byeloruss State, which was called The Grand Duchy of Lithuania. "In the second half of the $15^{\text {th }}$ century the third stage held" Duchy changed from the federation to the unitary state". It is in this form that the Grand Duchy of Lithuania will become part of the unitary Polish-Lithuanian Commonwealth in 1569 (Zaikyn, 2004: 77-78). In addition, the scientist expressed an interesting reflection on the effects of the Union of Krevo regarding the issues we are investigating: "Until 1569 this connection was very weak and had either the form of the Polish kings protectorate over the Grand Duchy, or the personal union of the Kingdom and the Grand Duchy" (Zaikyn, 2004: 78).

In contemporary historiography, the critic of the so-called "federal concept" is Lithuanian researcher Z. Norcus. The methodological basis was the teaching by M. Romerys one of the most famous theorists of the state. When developing the classification for forms of state structure, he proposed to add to the classic three types (federation, confederation, unitary state) the fourth one empire (Norkus, 2016: 139). In fact, Z. Norcus, considering this theory and analyzing the works of many historians, came to the following conclusion: "We will not find sufficient reasons to consider the GDL to be a federation. There was no equality between the lands that formed the GDL. The metropolis and the rest of lands "annexes" ...had been bound by the relations of subordination. The Rus lands did not have parity representation in the central authorities of the GDL or in its ruling elite. The 
"annex" is not an equal member of a constituted state, as it should be in the federation" (Norkus, 2016: 256). Moreover, the scientist believes that exactly the arguments of the supporters for "the federal character of the GDL system ... testify about something quite different, namely, showing not the federal but imperial character of the GDL" (Norkus, 2016: 264).

So, let's summarize. To date, there is no thoroughly historical and legal study in historical science that would solve the problem of determining the state structure of the GDL. The coryphaeuses in lithuanistics (M. Lyubavsky, M. DovnarZapolsky, etc.), followed by other scholars (including the modern ones), claimed the federal character of the entire state. This concept received reasoned criticism from scholars of different periods. However, not all of them offered their own classification option. The exceptions are the works of V. Zaikin and Z. Norkus. Their conclusions are fully reasoned and have the right to exist. At the same time, in our opinion, V. Zaikin pointed out the algorithm for solving the problem, paying attention to the possible periods of change in the form of the state structure of the GDL. It is quite clear that the state structure of the Grand Duchy of Lithuania before the beginning of Vitovt reign was completely changed during his rule (a vivid example is the political and legal status of the Podil Principality). Becides various reforms in the GDL after Vitovt could not help but touch to the political and legal sphere. Therefore, in our view, there is now a need for specialized historical studies to address this complex problem. This need is emphasized by the fact that the GDL authorities had consistently declared compliance with the principle of "we do not move antiquities and we do not introduce innovations", which did not correspond to practical realities.

\section{BIBLIOGRAPHY}

Ващук Д. Подільське князівство у другій половині XIV ст.: особливості правового статуту. Український історичний журнал, 2018, № 2, 4-19.

Грушевський М. Історія Украӥни-Руси: в 11т., 12 кн. Т. V: Суспільно-політичний і церковний устрій і відносини в українсько-руських землях XIVXVII віків. Київ: Наукова думка, 1998, 687.

Гудавичюс Э. История Литвы. Том I: С древнейших времён до 1569 года. Москва: Фонд им. И. Д. Сытина, Baltrus, 2005, 680.

Довнар-Запольский М. Государственное хозяйство Великого княжества Литовского при Ягеллонах. Киев: Типография Императорского университета св. Владимира, 1901, т. I, VIII+807+XII.

Ефименко А. История украинского народа. Санкт-Петербург: Издание Акц. общ. "Брокгауз-Ефрон", 1906, вып. 1, 192.

Заїкин В. Головні моменти української державності. Молода нація, 2004, № 2 (31), 77-78. 
Лащенко Р. Лекції по історії українського права. Частина друга: Литовськопольська доба, випуск перший: Памятники права. Прага: Наклад «Українського правничого товариства в Ч.С.Р.», 1924, 77.

Леонтович Ф. Очерки по истории Литовско-русского права. Образование территории Литовского государства. Санкт-Петербург: Типография В. С. Балашева и $\mathrm{K}^{\circ}, 1894, \mathrm{VI}+[2]+393$.

Любавский М. Областное деление и местное управление Литовско-русского государства ко времени издания Первого Литовского Статута. Москва: Университетская типография, 1892, 884+VI.

Любавский М. Очерк истории Литовско-Русского государства до Люблинской унии включительно. С приложением текста хартий, выданных Великому княжеству Литовскому и его областям. Москва: Московская художественная печатня, 1915, 401+III.

Молчановский Н. Очерк известий о Подольской земле до 1434 года (преимущественно по летописям). Киев: [б. и], 1885, 388+II+II+XXXI.

Норкус 3. Непроголошена імперія: Велике князівство Литовське з погляду порівняльно-історичної соціології імперій / пер. $з$ лит. Петро Білинський. Київ: Критика, 2016, 440.

Русина О. В. Україна під татарами і Литвою. Київ: Альтернативи, 1998, 320. (Україна крізь віки. Т. 6).

Чубатий М. Огляд історії українського права: історія джерел та державного права (Записки за викладами на Тайному Українському університеті у Львові в рр. 1920-1923). Мюнхен: [б. в], 1947, ч. II, 175.

Шабульдо Ф. Земли Юго-Западной Руси в составе Великого княжества Литовского. Киев: Наукова думка, 1987, 185 с.

\section{REFERENCES}

Chubatyi, 1947 - Chubatyi, M. (1947). Ohliad istorii ukrainskoho prava: istoriia dzherel ta derzhavnoho prava (Zapysky za vykladamy na Tainomu Ukrainskomu universyteti u Lvovi v rr. 1920-1923) (Vol. II). Miunkhen. [in Ukrainian].

Dovnar-Zapolskyi, 1901 - Dovnar-Zapolskyi, M. (1901). Hosudarstvennoe khoziaistvo Velykoho kniazhestva Lytovskoho pry Yahellonakh (Vol. I). Kiev: Typohrafyia Ymperatorskoho unyversyteta sv. Vladymyra. [in Russian].

Efymenko, 1906 - Efymenko, A. (1906). Istoryia ukraynskoho naroda (Vol. 1). Sankt-Peterburh: Yzdanye Akts. obshch. "Brokhauz-Efron". [in Russian].

Hrushevskyi, 1998 - Hrushevskyi, M. (1998). Istoriia Ukrainy-Rusy: v 11 t., 12 kn. T. V: Suspilno-politychnyi i tserkovnyi ustrii i vidnosyny v ukrainsko-ruskykh zemliakh XIV-XVII vikiv. Kyiv: Naukova dumka. [in Ukrainian].

Hudavychius, 2005 - Hudavychius, E. (2005). Ystoryia Lytvy. Tom I: S drevneishykh vremen do 1569 hoda. Moskva: Fond ym. Y. D. Sytyna, Baltrus. [in Russian]. 
Lashchenko, 1924 - Lashchenko, R. (1924). Lektsii po istorii ukrainskoho prava. Chastyna druha: Lytovsko-polska doba, vypusk pershyi: Pamiatnyky prava. Praha: Naklad «Ukrainskoho pravnychoho tovarystva v Ch.S.R.». [in Ukrainian]. Leontovych, 1894 - Leontovych, F. (1894). Ocherky po ystoryy Lytovsko-russkoho prava. Obrazovanye terrytoryy Lytovskoho hosudarstva. Sankt-Peterburh: Typohrafyia V. S. Balasheva y $\mathrm{K}^{\circ}$. [in Russian].

Liubavskyi, 1892 - Liubavskyi, M. (1892). Oblastnoe delenye y mestnoe upravlenye Lytovsko-russkoho hosudarstva ko vremeny yzdanyia Pervoho Lytovskoho Statuta. Moskva: Unyversytetskaia typohrafyia. [in Russian].

Liubavskyi, 1915 - Liubavskyi, M. (1915). Ocherk ystoryy Lytovsko-Russkoho hosudarstva do Liublynskoi unyy vkliuchytelno. S prylozhenyem teksta khartyi, vydannykh Velykomu kniazhestvu Lytovskomu y eho oblastiam. Moskva: Moskovskaia khudozhestvennaia pechatnia. [in Russian].

Molchanovskyi, 1885 - Molchanovskyi, N. (1885). Ocherk yzvestyi o Podolskoi zemle do 1434 hoda (preymushchestvenno po letopysiam). Kiev. [in Russian].

Norkus, 2016 - Norkus, Z. (2016). Neproholoshena imperiia: Velyke kniazivstvo Lytovske z pohliadu porivnialno-istorychnoi sotsiolohii imperii. Kyiv: Krytyka. [in Ukrainian].

Rusyna, 1998 - Rusyna, O. (1998). Ukraina pid tataramy i Lytvoiu. Kyiv: Alternatyvy. [in Ukrainian].

Shabuldo, 1987 - Shabuldo, F. (1987). Zemly Yuho-Zapadnoi Rusy v sostave Velykoho kniazhestva Lytovskoho. Kiev: Naukova dumka. [in Russian].

Vashchuk, 2018 - Vashchuk, D. (2018). Podilske kniazivstvo u druhii polovyni XIV st.: osoblyvosti pravovoho statutu. Ukrainskyi istorychnyi zhurnal, 2, 419. [in Ukrainian].

Zaikyn, 2004 - Zaikyn, V. (2004). Holovni momenty ukrainskoi derzhavnosti. Moloda natsiia, 2, 77-78. [in Ukrainian]. 